\title{
Investigation of Attitudes and Behaviors Related to Rational Drug Use in Adana Province Havutlu District
}

\author{
Adana İli Havutlu İlçesinde Akılcı İlaç Kullanımına İlişkin \\ Tutum ve Davranışların İncelenmesi \\ Ersin Nazlican \\ Çukurova Üniversitesi Tip Fakültesi Halk Sağglğ̆ AD \\ Yazışma Adresi / Correspondence: \\ Ersin Nazlican \\ Cukurova Üniversitesi Tip Fakültesi Halk Sağlığı AD \\ T: +905057165836 E-mail : e.nazlican@gmail.com \\ Geliș Tarihi / Received : 29.07.2020 Kabul Tarihi / Accepted : 25.09.2020 \\ Orcid : \\ Ersin Nazlican, https://orcid.org/0000-0002-1460-1996 \\ ( Sakarya Tip Dergisi / Sakarya Med J 2020, 10(4):572-579 ) DOI: 10.31832/smj.775311
}

\begin{abstract}
Objective Rational drug use is a process involving healthcare providers, legislators and the whole society. Here, we aimed to investigate the attitudes and behaviors related to 'Rational Drug Use' in Havutlu district of Adana province.

Materials In our study, we conducted a questionnaire consisting of 28 questions about the sociodemographic characteristics and the attitudes and behaviors related to "Rational and Methods Drug Use" we implemented. The sample size is 358 . We also acquire the necessary statutory authorizations and approval of the ethics committee. The type of study is crosssectional. In analysis, frequency analysis and chi-square test were used with SPSS version 19.0.

Results Average of $4.1 \pm 2.6$ box medicine was left unused. $26 \%$ of the participants stated that they offered medication to their relatives, and the use of herbal medicines been found as $15.9 \% .87 .7 \%$ of the participants stated that the medication was overturned after the expiry date and $3.4 \%$ would continue to use it. The average annual antibiotic use of the participants was found to be $2.3 \pm 1.4$ and $59.8 \%$ of those who took antibiotic treatment stated that they terminated the treatment voluntarily without ending the treatment period. In order to be found at home, the prescription for medication seems to be significantly higher in women with a level of income below 1,000 TL ( $\mathrm{p}=0.02$ ) and with chronic disease $(\mathrm{p}<0.001)$. The presence of chronic illness appears to be associated with both herbal medication use $(\mathrm{p}<0.001)$ and home medication $(\mathrm{p}=0.008)$.

Conclusion When attitudes and behaviors related to rational drug use are examined, it is concluded that some variables have an influence and that inappropriate use is common throughout the society.

Keywords Rational drug use; expired drug; rational antibiotic use.

Öz

Amaç Akılcı ilaç kullanımı sağlı hizmeti sağlayıcıları, yasa koyucular ve tüm toplumu kapsayan bir süreçtir. Bu çalş̦smada, Adana’nnn Havutlu ilçesinde 'Akılcı İlaç Kullanımı' ile ilgili tutum ve davranışları araştırmayı amaçladık.

Gereç ve Çalışmamızda sosyo-demografik özellikler ile uyguladığımız "Akılcı Ilaç Kullanımı" ile ilgili tutum ve davranışlar hakkında 28 sorudan oluşan bir anket gerçekleștirdik. Örneklem büyüklü̆üu Yöntemler 358’dir. Ayrıca gerekli yasal izinler ve etik kurul onayı alımıstır. Calısma türü kesitseldir. Analizlerde SPSS 19.0 sürümü ile frekans analizi ve ki-kare testi kullanılmıstır.

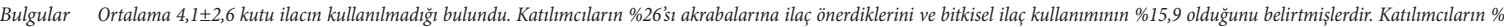

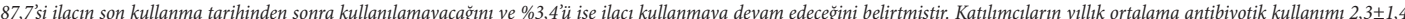
olarak bulundu. Antibiyotik tedavisi alanları \% 59,8 ' i tedavi bitmeden tedaviyi gönüllü olarak sonlandırdıklarını belirtmiștir. Evde bulunabilmesi için 1.000 TL’nin altında geliri olanlarda $(p=0,02)$ ve kronik hastalı̆̆ $(p<0,001)$ olan kadınlarda ilaç reçetesi sayısı önemli ölçüde daha yüksek bulundu. Kronik hastalık varllğı hem bitkisel ilaç kullanımı $(p<0,001)$ hem de evde ilaç tedavisi $(p=0,008)$ ile ilișkili görünmektedir.

Sonuç Akılcı ilaç kullanımına iliskin tutum ve davranıșlar incelendiğinde, bazı değişkenlerin etkili olduğu ve toplumda uygunsuz kullanımın yaygın olduğu sonucuna varılmıstır.
\end{abstract}




\section{INTRODUCTION}

According to the World Health Organization; drug is defined as a substance or a product that is used or intended to be used for the purpose of modifying, examining, physiological states or pathological events for the benefit of the user.

Using some plants for health problems is as old as human history. The desire of people to obtain medicines from the products of the nature is based on ancient times according to the evidence obtained from important historical documents such as written documents, monuments. Today's science has accepted some of these drugs and has included some herbal medicines that have been used for thousands of years. ${ }^{1}$

Today, medical drugs are one of the most important elements of modern medicine health presentation tools. Up to the previous century, man was able to use a limited number of medicines. Over the past 100 years, thousands of new medicines have become available and the number and variety of medicines have increased, and it becomes easier to access. Drug use has been well diversified with many factors affecting the possibilities of countries. Over time, this caused the problem of information pollution and misuse. ${ }^{2}$

While medicines are used, "the principle of benefit and harm", which is the most important principle of medicine, must be observed. Otherwise, it may be exposed to increased side effects or multiple drug reactions as a result of improper handling. Besides, it hurts the country's economy. People have known the harm/damages of usage for thousands of years. As Herophilus at 300 B.C. said, "Drugs are nothing on their own, and if they are used with wisdom and prudence, they are the hand of God." ${ }^{3}$

In order to prevent these damages, the basis of the measures started to be taken by the World Health Organization in Nairobi, Kenya in 1985 and the concept of "Rational
Drug Use" (RUD) It has also been defined as "the use of drugs at the lowest cost for them, and for a sufficient period of time, at doses that meet their individual needs and are appropriate to the clinical needs of the patients." The inadequate use of medicines is a health problem all over the world that is also important for the health system, especially for the community. ${ }^{5}$ The use of this irrational drug can have different effects in many ways:

- Decreased drug treatment quality leads to increased morbidity and mortality,

- Waste of resources that cause other vital drugs to be reduced,

- The risk of undesirable effects, such as the occurrence of adverse drug reactions and drug resistance (eg, malaria or multiple-infection resistant bacteria)

- The effect on the psychosocial status of patients, for example, can lead to a belief that a medication is good for every illness, and a clearly increasing demand for these medications. ${ }^{6}$

Non-rational use is a common problem in all countries of the world. Generally, non-rational drug types are:

- Too many medications per patient (polypharmacy);

- Non- bacterial infections inappropriate and incorrect dosing;

- Excessive use of injections when oral formulations are more appropriate;

- Not being prescribed in accordance with clinical guidelines;

- Inappropriate self medication - mostly prescription drugs $^{7}$

- Patient incompatibility in tuberculosis treatment6

Herbal medicine use; has been increasing in the world in recent years. Unconscious and unsafe uses of herbal medicines have also been selected for inclusion in national health programs. Some herbal medicines are strong and people's safety is not as clear as people think. They can also be dangerous when combined with modern medicines. ${ }^{8}$ 
Antibiotic resistance: Antimicrobial agents have played a key role in controlling infectious diseases since they were developed. On the other hand, the result of ever-increasing use has resulted in the formation of disease-resistant microorganisms in hospital settings. As we have not succeeded in developing new antibiotics in the last few decades, it is difficult to combat resistant organisms. ${ }^{9}$ Antibiotic resistance is one of the greatest threats to today's global health, food safety and development. ${ }^{10}$

Drug residues: Consumption will increase steadily with the ease of access to lower-cost drugs, and the world's population will exceed 8 billion in the near future. Commonly used preventive medicines such as statins and antihypertensives and cheap generic drugs increase the problem. The UK Statistics Office predicts that the country will double its drug use by $2050 .{ }^{11}$

Non-rational drug use is global. Inefficient use of medicines is available all over the world, medically unsuitable, ineffective and financially affordable. But developing countries are worse than developed countries in this respect. ${ }^{12}$ Any mistake that directly or indirectly concerns the use of medicines can be described as non-rational drug use. Where there is a problem of non-rational drug use, there are the responsibilities of various institutions and organizations ranging from physicians to pharmacists, nurses to other people working in health centers, health authorities to health institutions and reimbursement institutions to pharmaceutical companies. ${ }^{2}$

When looking at the underlying factors of non-rational drug use, there are cases in which the physician, the patient, the workplace, the industry, the drug providers are caused. ${ }^{6}$

The pharmaceutical sector in the world, about 1.2 trillion dolar is spent for Medicines in 2016 with about 5\% growth since 2000's. In the United States, total drug spending is \$ 333 billion (1.9\% of GDP, $10.7 \%$ of total health spending).
As a result, the United States has spent \$1,036 per person per year. ${ }^{13}$ The aimed of this study; investigate the attitudes and behaviors related to 'Rational Drug Use' in Havutlu district of Adana province.

\section{MATERIALS and METHODS}

This study is a cross-sectional study aimed to evaluate the attitudes and behaviors of rational drug use by people over 18 years of age living in Adana Province Havutlu District. Cukurova University Medical Faculty Ethics Committee has been approved for research. (Ethics committee approval: decision no: 47 of 6 November 2015) The researcher's universe constitutes individuals living in Havutlu District. While the sample size is being calculated, Adana Province Havutlu District, all of the population over 18 years of age were taken with a $95 \%$ confidence interval and an error margin of 0.05 . With reference to the World Health Organization data, rational drug use rates and required sample size were calculated as 358 persons. A simple random sample selection method was applied to the population over 18 years of age. The necessary permits were obtained from the Governorship of Adana and the Ministry of Health for the research.

In addition to questions involving socioeconomic status such as age, gender, educational status, income level of persons, questions about the behaviors that are frequently made by the community regarding rational drug use are included. Permission was obtained from those who participated in the study. In this context, 28 questions were asked in the questionnaire and asked to respond. Some demographic data and behavior related to Rational Drug Use were recorded. In the evaluation of these data, frequency analysis and chi-square tests were used. SPSS 19.0 for Windows was used for statistical evaluations.

\section{RESULTS}

The research was carried out in 358 adults living in the Havutlu district of Adana province. The youngest of the participants was 18 , the oldest was 86 years old and the av- 
erage age was $45.82 \pm 15.27$ and $53.1 \%$ (190 persons) were male and $46.9 \%$ (168 persons) were female.

When participants were asked whether they had a chronic illness, $41.9 \%$ (150 people) had at least one chronic illness and $58.1 \%$ (208 people) did not have any chronic health problems.

The average annual use of antibiotics was found $2.3 \pm 1.4$. The participants were questioned if they left the antibiotic treatment before recommended period; 59.8\% (214 persons) stated that they terminated the treatment voluntarily before the recommended period and 40.2\% (144 persons) continued until the end of the treatment.

In our study group, $80.4 \%$ (288 people) of them were informed about how many days and what doses of medicines should be used by health workers and 19.6\% (70 people) stated that they did not receive information on these subjects.

53.1\% (193 people) stated that they did not ask for prescription of any medicines while $\% 46.1$ said they asked for prescription of medicines to be at home.

When we asked the participants whether they had drugs in their homes, $88.5 \%$ (317 people) said that they had at least one box of medicines at homes and $11.5 \%$ (41 people) said that they did not have any medicines at.

When they were asked what they were doing with the remaining medicines after participant treatment, 85.2\% (305 people) kept it at home, $3.9 \%$ (14 people) gave it to others, and $5.0 \%$ (18 people).

\begin{tabular}{|l|c|c|c|}
\hline \multicolumn{4}{|l|}{ Table 1. General Questions About Drug Use } \\
\hline Drug Use & Yes & 214 & $\mathbf{n}$ \\
\hline \multirow{2}{*}{ Treatment Termination } & No & 144 & 40.8 \\
\hline \multirow{2}{*}{ Prescription for being at home } & Yes & 165 & 46.1 \\
\cline { 2 - 4 } & No & 193 & 53.9 \\
\hline \multirow{2}{*}{ Availability of medication at home } & Yes & 317 & 88.5 \\
\cline { 2 - 4 } & No & 41 & 11.5 \\
\hline Total & & $\mathbf{3 5 8}$ & $\mathbf{1 0 0}$ \\
\hline
\end{tabular}

41.1\% (150 people) think that herbal medicines could be used and $58.1 \%$ (208 people) think that herbal medicines should not be used when they were asked about using herbal medicines. Participants stated that 15.9\% (57 people) had herbal remedies at home and $84.1 \%$ (301 people) did not have herbal remedies at home when we asked about the presence of herbal remedies at home.

When asked about expired medicines, $87.7 \%$ (314 people) discarded them, $3.4 \%$ (12 people) continue to use, $8.9 \%$ (32 people) stated that they deliver to the health care provider. There is a significant correlation between. ( $p<0.001)$. However, no significant difference was found between age, gender, education, working status, income level, and view about herbal remedies. 
Sakarya Med J 2020;10(4):572-579

NAZLICAN, Investigation of Attitudes and Behaviors Related to Rational Drug Use

\begin{tabular}{|c|c|c|c|c|c|c|c|c|}
\hline \multirow{3}{*}{ Variables } & \multirow{3}{*}{ Groups } & \multicolumn{4}{|c|}{$\begin{array}{l}\text { Thinking about the use of herbal } \\
\text { medicine }\end{array}$} & \multirow{2}{*}{\multicolumn{2}{|c|}{ Total }} & \multirow{3}{*}{$\mathbf{p}$} \\
\hline & & \multicolumn{2}{|c|}{ Positive } & \multicolumn{2}{|c|}{ Negative } & & & \\
\hline & & $\mathbf{n}$ & $\%$ & $\mathrm{n}$ & $\%$ & $\mathbf{n}$ & $\%$ & \\
\hline \multirow{2}{*}{ Age } & Under 45 & 60 & 36.8 & 103 & 63.2 & 163 & 45.5 & \multirow{2}{*}{$\mathrm{p}=0.07$} \\
\hline & 45 and over & 90 & 46.2 & 105 & 53.8 & 195 & 63.1 & \\
\hline \multirow{2}{*}{ Gender } & Woman & 78 & 46.4 & 90 & 53.6 & 168 & 46.9 & \multirow{2}{*}{$\mathrm{p}=0.102$} \\
\hline & Male & 72 & 37.9 & 118 & 62.1 & 190 & 53.1 & \\
\hline \multirow{2}{*}{ Education status } & Under high school & 112 & 44.6 & 139 & 55.4 & 251 & 70.1 & \multirow{2}{*}{$\mathrm{p}=0.110$} \\
\hline & High school and over & 38 & 35.5 & 69 & 64.5 & 107 & 29.9 & \\
\hline \multirow{2}{*}{ Working Status } & Employed & 76 & 40.4 & 112 & 59.6 & 188 & 52.5 & \multirow{2}{*}{$\mathrm{p}=0.552$} \\
\hline & Unemployed & 74 & 43.5 & 96 & 56.5 & 170 & 47.5 & \\
\hline \multirow{2}{*}{ Income Level } & Below 1,000 TL & 60 & 45.5 & 72 & 54.5 & 132 & 36.9 & \multirow{2}{*}{$\mathrm{p}=0.297$} \\
\hline & 1,000 TL over & 90 & 39.8 & 136 & 60.2 & 226 & 63.1 & \\
\hline \multirow{2}{*}{ Chronic Disease } & Yes & 78 & 52 & 72 & 48 & 150 & 41.9 & \multirow{2}{*}{$\mathrm{p}=0.001$} \\
\hline & No & 72 & 34.6 & 136 & 65.4 & 208 & 58.1 & \\
\hline
\end{tabular}

\section{DISCUSSION}

Along with the increasing proportion of elderly population and new treatment methods, acute diseases are mostly responsible for chronic diseases. Increasing chronic diseases require more drug use, leading to more adverse effects and multiple drug reactions. The need for health is being reshaped in accordance with the needs of the end-users with social change and increasingly aging population.

When we look at the variables involved in our study, results of prescribing more drugs to the women, using more drugs for people with chronic diseases, and using more drugs for the elderly are very similiar in all European Union countries and also similiar results in our study.

Annual average antibiotic use was found to be 2.3 in our study. In the work done by Büke et al. the use of antibiotics was reported as 54.4\%. ${ }^{14}$ According to Nayir et al.s study, $55.5 \%$ of patients use antibiotics in their own incision. ${ }^{15}$ Participants in the Pinar's thesis state that $47.9 \%$ of them left treatment before completing the period was, while $52.1 \%$ stated that they complete treatment. ${ }^{16}$ In a survey conducted in 2011 in China, which is considered as one of the developing countries, $70.8 \%$ stated that they quit anti- biotics after symptoms were over. ${ }^{17}$ In our study, 59.8\% of 358 people stated that they left antibiotic treatment with their own decision.

A study conducted by Oğuz and his colleagues found that $15.9 \%$ of patients had been prescribed drugs without illness. ${ }^{18}$ In the study of Pinar, $28.9 \%$ of those who participated in the study stated that they were to request of prescription drugs to stay at home. Women were found to be more drug-conscious than men. They thought it was because most of the women in their studies were housewives and had time to request of prescription the medicines. There was a significant relationship between having a chronic illness and antibiotic consumption and home medication. It is estimated that this relationship is due to more visits to the doctor in addition.

In terms of environment and drug use, $17.0 \%$ of respondents said that they use medicines with environmental advice and $25.3 \%$ recommend medicines to their benefactor. ${ }^{19}$ In the study of Oğuz and his colleagues, $22 \%$ of the patients stated that they would like to prescribe medication with their neighbors and / or close proposals, and $5.1 \%$ stated they were familiar, neighbors or relatives ac- 
quire information while they were using medicines they had at home. ${ }^{18}$ In our study, $26.0 \%$ of respondents in the study group had suggested that they offered medication to their relatives. In all studies conducted in our country, although rates vary according to regions, drug abstinence rates are high.

Donmez and his colleagues conducted an average of 80 out of 100 households with one or more medicines and an average of 4.34 boxes of medicines for each house. ${ }^{20}$ In a study by Göçgeldi and his colleagues, $61.3 \%$ of the participants stated that there was residual medicine in their homes. ${ }^{21}$ In the study of Özkan et al., $44.8 \%$ of the participants stated that they have drugs they did not use at home. ${ }^{22}$ In the study of Hatipoğlu and Özyurt, the percentage of those who had medication was found to be $85.5 \% .{ }^{23}$ There was a significant relationship between the presence of half-box or unused medication at home and the presence of chronic illness.

In the study of the Ministry of Health, $65 \%$ of the patients who applied to the Family Health Centers and $63.9 \%$ of the patients who applied to the State Hospitals said that they had drugs at home which had overturned expiry day. ${ }^{24}$ In a study conducted by Baybek et al., the discarding rate of drugs with expiration date was $92.4 \% .{ }^{25}$ The work done by the Yap1c1 and colleagues found that the discarding rate of the drugs that passed the expiration date was $90.4 \% .{ }^{19}$ In the study of Hatipoğlu and Özyurt, the percentage of those who used past-expired drugs remained at $8.5 \% .{ }^{23}$ In our study, $3.4 \%$ of those who agreed to respond to the questionnaire indicated that they could consume the drug that passed the expiration date. $87.8 \%$ of the respondents said that they use drugs after the expiry date.

When we look at the behaviors related to herbal treatment, Erenler and Koçoğlu's research shows that $38.3 \%$ of the respondents use alternative medical treatments, $24.8 \%$ use drugs according to their own experience. ${ }^{26}$ In Karataş et al.s study, its asked that if they use herbal remedies, if they do not benefit from doctor and $89 \%$ of participants indicated that they would apply, 6.7\% would refer to it, and $4.3 \%$ would not. ${ }^{27}$

In a study in Isparta, $86.1 \%$ of traditional treatment applications were found to be herbal medication. As chronic illness and those that have had higher than those without reference to conventional treatment. ${ }^{28}$ In our study, no significant association was found with education status, income, gender, and it was seen that the presence of chronic illness had a meaningful effect on more favorable treatment of herbal medicines and keeping them at home. In Pinar's thesis study, it was found that $49.4 \%$ of the people applied herbal remedies at home. ${ }^{16}$

In our study, $41.9 \%$ thought that herbal medicines should be used, while $15.9 \%$ found that they had herbal medicines at home. There is no significant relation between age, gender, education level, working status, income level and the presence of herbal remedies and the use of herbal remedies in a meaningful manner, but both has a significant relation in the presence of chronic illness. This is thought to be due to the fact that people with chronic illnesses tend to try alternative treatment methods if the disease can't be completely eliminated and this is often not achieved.

\section{CONCLUSIONS}

Patient and its relatives' drug use behaviors are important in terms of rational drug use, a preventable public health problem that both affects people's health negatively and causes us to live in economic loss. When we examine the factors related to rational drug use in this direction; the progressive average of antibiotic use was found to be $2.3 \pm 1.4$. When the participants were questioned if they completed the antibiotic treatment, it was found that $59.8 \%$ of the participants did not complete the treatment.

Half-box or no-used medication was found to be 4.1 \pm 2.6 . $88.5 \%$ of participants have medication at home. $46.1 \%$ of the participants stated that they were asking to practition- 
er to prescribe drugs to keep at home.

91.1\% of respondents are throwing away drugs that have expired. Because women are mostly housewives, it is presumed that individuals in the household are more likely to request medication, prescribe, and tend to be tacky in order to take their medication. $41.9 \%$ of participants stated that herbal remedies should be used, $15.9 \%$ of them have herbal remedies at home. There is also a significant relationship between the presence of chronic illness and the thought of using herbal remedies and the presence of herbal remedies at home.

Frequent mistakes made by patients in the rational drug use in our country are to demand antibiotics and other medicines, to recommend to neighbor and guests, to use medicines without consulting a doctor, to keep a lot of medicines at home, to throw away medicines with expiry date mostly and to use herbal medicines unconsciously.

Associated with it;

- When prescribing antibiotics, the duration of treatment should be specified, the patient should not left before completion, drugs should not be requested from doctors, and society should be trained about not recommending drugs to each other.

- The expiry date of medicines is important in terms of the protection of public health due to the environmental health. These should be trained.

- The community must be convinced that using herbal medicines is a serious issue and the official regulations governing their sale and procurement should be audited.

- The elder population is increasing in our country. In order not to cause resource deficiencies in the health system, efforts should be made to reduce the occurrence of chronic diseases, to obtain the behaviors necessary to live a healthy life, to pay attention to public health measures that are cheaper and more effective than the second step, resources should be used in this direction.

\section{Research Support}

Our study was supported by Çukurova University Scientific Research Projects Unit. There is no support or interest conflict from any person or organization.

\section{Limitations of the Study}

The survey also looked at factors related to people misdiagnosing or memory. It is the limitations of researching probable behaviors such as custody, avoidance, and the consequences of the person who conducts the survey as a doctor.

Cukurova University Medical Faculty Ethics Committee has been approved for research. (Ethics committee approval: decision no: 47 of 6 November 2015) 
Sakarya Med J 2020;10(4):572-579

NAZLICAN, Investigation of Attitudes and Behaviors Related to Rational Drug Use

\section{References}

1. Petrovska BB. Historical review of medicinal plants' usage. Pharmacognosy Reviews. 2012;6(11):1-5.

2. T.C. Sosyal Güvenlik Kurumu Başkanlı̆̆ı, Topluma Yönelik Akılcı İlaç Kullanımı, 2013 SGK Yayin No: 93 ISBN: 978-605-63932-4-2 Ankara, 2013

3. Borzelleca J. F., Paracelsus. Herald of Modern Toxicology. Toxicol Sci; 200053 (1): 2-4.

4. World Health Organization. The rational use of drugs : report of the Conference of Experts, Nairobi, 1985

5. Ofori-Asenso, R.; Agyeman, A.A. Irrational Use of Medicines-A Summary of Key Concepts. Pharmacy 2016, 4, 35

6. PanAmerican Health Organisation, Problems of Irrational Drug Use Session Guide, 2010

7. World health Organisation, WHO Policy Perspectives on Medicines, Promoting Rational Use of Medicines: Core Components, No. 005, September 2002

8. World Health Organization. How to investigate the use of medicines by consumers, 2004

9. Laxminarayan R, Duse A, Wattal C, Zaidi AK, Wertheim HF, Sumpradit N et al. Antibiotic resistance-the need for global solutions. The Lancet Infectious Diseases. 2013;13(12):105798

10. World Health Organisation, Antibiotic resistance Fact sheet, Geneva, 2016

11. Homedes N, Ugalde A. Patients' compliance with medical treatments in the Third World. What do we know? Health Policy and Planning, 1993, 8(4):291-314

12. Brahma D., Marak M., Wahlang J. Rational Use of Drugs and Irrational Drug Combinations, The Internet Journal of Pharmacology, 2012 Volume 10 Number 1

13. United States of America, Department of Commerce. 2016 Top Markets Report Pharmaceuticals, 2016

14. Büke Ç., Șahin H., Sivrel A., Çalık Ș.Ö., Özbakkaloğlu B. Tip Fakültesi Son Sintf Öğrencilerinin Akılcı Antibiyotik Kullanımı Konusundaki Bilgi ve Davranışları, Tip Eğitimi Dünyası Sayi: 17, 2004, 11

15. Nayir T., Okyay R.A., Yesilyurt H, Akbaba M., Nazlican E., Acık Y., Akkus H.I. Assessment of rational use of drugs and self-medication in Turkey: A pilot study from Elazig and its suburbs. Pakistan journal of pharmaceutical sciences. 2016, 29. 1429-1435.

16. Pınar N. Uzmanlık tezi, Adana İlindeki İnsanların İlaç Kullanım Alışkanlıkları. Çukurova Üniversitesi Tip Fakültesi, Adana, 2010
17. Zhu, X. et al. Self-medication practices with antibiotics among Chinese university students, Public Health, 2015, Volume 130, $78-83$

18. Oğuz E., Alaşehirli B., Demiryürek A.T. Gaziantep Üniversitesi Tip Fakültesi Şahinbey Araştırma Ve Uygulama Hastanesi’nde Yatan Hastaların Akılcı İlaç Kullanımı İle İlgili Davranışlarının Değerlendirilmesi, Harran Üniversitesi Tip Fakültesi Dergisi, Cilt 12. Sayı 2, 2015

19. Yapıcı G., Balıkçı S., Uğur Ö. Birinci basamak sağlık kuruluşuna başvuranların ilaç kullanımı konusundaki tutum ve davranışları, Dicle Medical Journal, 2011; 38 (4): 458-465

20. Dönmez L, Yüzgül N, Anaç CC, Ödemiș Y, Özel F. Antalya Merkez 6'nolu Sağllk Ocağı Bölgesindeki Hanelerde Kullanılmayan Illaçların Durumu. 8. Halk Sağlı̆̆ı Günleri, Halk Sağllğı ve Sosyal Bilimler Bildiri Özetleri. Sivas:23-25 Haziran 2003.s.60.

21. Göçgeldi E., Uçar M., Açıkel C.H., Türker T., Hasde M., Ataç A. Evlerde Artık İlaç Bulunma Sıklŭ̆ ve İlișkili Faktörlerin Araștırılması, TAF Preventive Medicine Bulletin. 2009: 8(2)

22. Özkan S., Özbay O.D., Aksakal F.N., İlhan M.N., Aycan S. Araștırma Bir Üniversite Hastanesine Başvuran Hastaların Hasta Olduklarındaki Tutumları Ve İlaç Kullanım Alışkanlıkları, TSK Koruyucu Hekimlik Bülteni, 2005: 4 (5) 223

23. Hatipoğlu S., Özyurt B.C. Manisa ilindeki bazı aile sağ lı̆̆ merkezlerinde akılcı ilaç kullanımi. TAF Preventive Medicine Bulletin 2016; 15(4): 277-284

24. Türkiye Cumhuriyeti Sağlık Bakanlı̆̆ı Refik Saydam Hıfzıssıhha Merkezi Bașkanlı̆̆ı Hıfzıssıhha Mektebi Müdürlüğü. Toplumun Akılct ilaç Kullanımına Bakışı, Ankara, 2011

25. Baybek H., Bulut D., Çakır A. Muğla Üniversitesi İdari Personelinin İlaç Kullanma Alș̣ kanliklarının Belirlenmesi, Muğla Üniversitesi Sosyal Bilimler Enstitüsü Dergisi, 2005, 15

26. Ekenler Ș., Koçoğlu D. Bireylerin Akılcı İlaç Kullanımıyla İlgili Bilgi ve Uygulamaları Individuals, Hacettepe Universitesi Hemşirelik Fakültesi Dergisi 2016, 3(3), 44-55

27. Karataş Y, Dinler B, Erdoğdu T, Ertuğ P, Seydaoğlu G. Çukurova Universitesi Tip Fakültesi Balcalı Hastanesine Başvuran Hasta ve Hasta Yakınlarının İlaç Kullanım Alışkanlıklarııın Belirlenmesi Çukurova Üniversitesi Tip Fakültesi Dergisi. 2012; 37(1):1-8

28. Öztürk M., Uskun E., Özdemir R., Çınar M., Alptekin F., Doğan M. Isparta İlinde Halkn Geleneksel Tedavi Tercihi, Turkiye Klinikleri J Med Ethics 2005, 13 